Provided for non-commercial research and education use. Not for reproduction, distribution or commercial use.

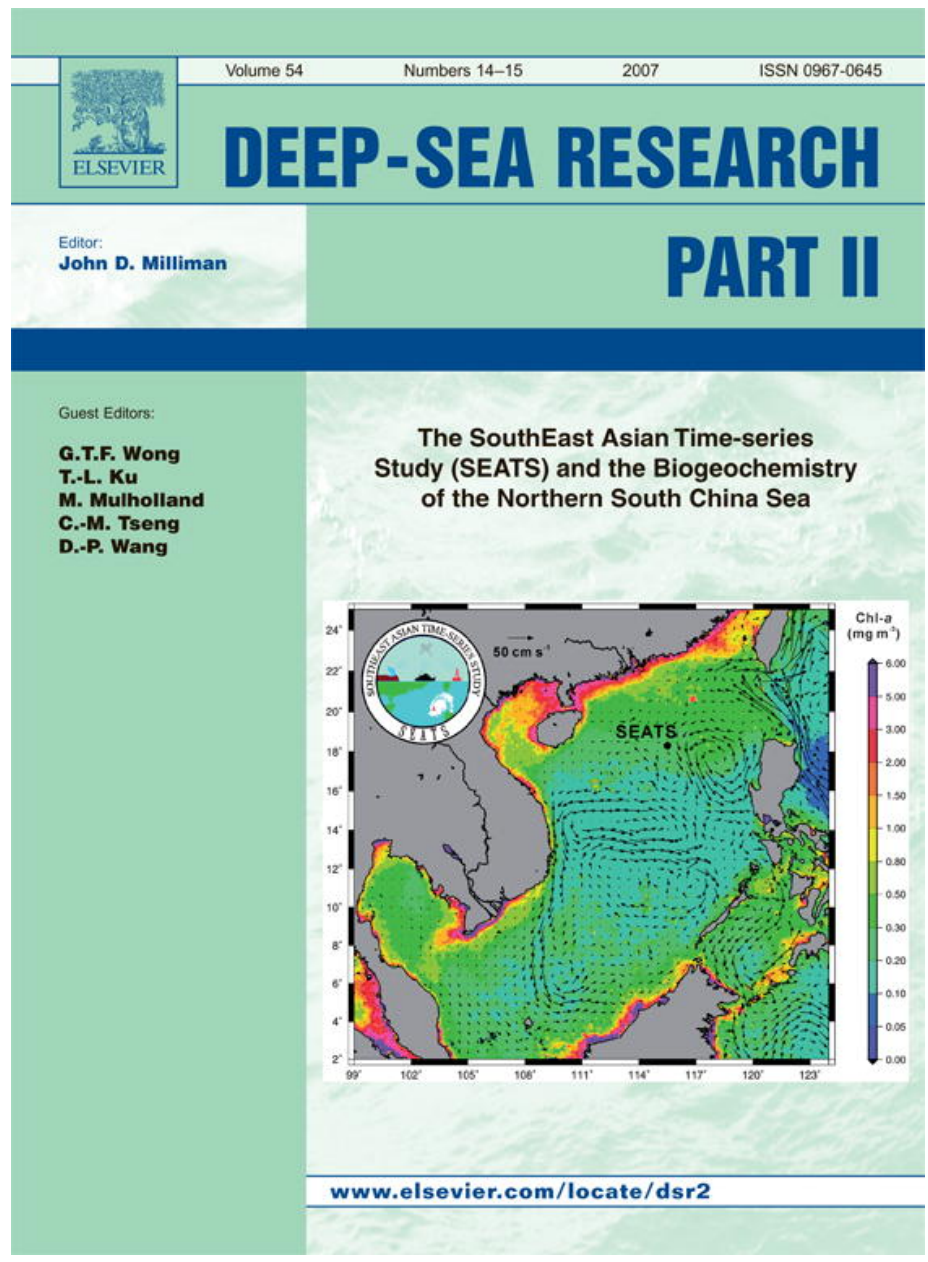

This article was published in an Elsevier journal. The attached copy

is furnished to the author for non-commercial research and education use, including for instruction at the author's institution, sharing with colleagues and providing to institution administration.

Other uses, including reproduction and distribution, or selling or licensing copies, or posting to personal, institutional or third party websites are prohibited.

In most cases authors are permitted to post their version of the article (e.g. in Word or Tex form) to their personal website or institutional repository. Authors requiring further information regarding Elsevier's archiving and manuscript policies are encouraged to visit: 


\title{
Aerosol input to the South China Sea: Results from the MODerate Resolution Imaging Spectro-radiometer, the Quick Scatterometer, and the Measurements of Pollution in the Troposphere Sensor
}

\author{
I-I Lin ${ }^{\mathrm{a}, *}$, Jen-Ping Chen ${ }^{\mathrm{a}}$, George T.F. Wong ${ }^{\mathrm{b}}$, Chih-Wei Huang ${ }^{\mathrm{a}}$, Chun-Chi Lien ${ }^{\mathrm{a}}$ \\ ${ }^{a}$ Department of Atmospheric Sciences, National Taiwan University, No. 1, Sec. 4, Roosevelt Road, Taipei 106, Taiwan \\ ${ }^{\mathrm{b}}$ Research Center for Environmental Changes, Academia Sinica, Taipei, Taiwan
}

Accepted 13 May 2007

Available online 20 August 2007

\begin{abstract}
Data from the MODerate Resolution Imaging Spectro-radiometer (MODIS) and other satellite sensors in 2002-2004 indicate that, in addition to locally produced sea-salt particles, aerosols from various remote sources also find their ways to the South China Sea, including industrial/urban pollution in eastern China, wind-blown dust from Asian deserts and biomass burning in Sumatra and Borneo. Among these sources, anthropogenic aerosols from eastern China are produced year round while desert dusts are produced primarily between February and April and biomass burning smoke from August to October. In terms of size of aerosols, sea salt and dust predominate the coarse mode while pollution and smoke predominate the fine-mode particles. Our study suggests that the aerosol input to the South China Sea come from different remote sources dependent upon the season, as opposed to a single dust source as previously anticipated. In the winter monsoon season from November to April, the prevailing northeasterly carries anthropogenic aerosols mixed with dust during dust outbreaks to the northern South China Sea. In the summer monsoon season from June to September, the prevailing southwesterly favours the transporting of smoke particles associated with biomass burning in Borneo and Sumatra to the southern South China Sea. The variety of remote aerosol sources associated with strong spatial and temporal variability of transporting aerosols to the region shows the complexity of atmospheric impact on the biogeochemistry in the South China Sea. Hence, an integrated research approach is deemed critical to assess the biogeochemical impact of these aerosols to the South China Sea.
\end{abstract}

(C) 2007 Elsevier Ltd. All rights reserved.

Keywords: Aerosol; Biogeochemical response; MODIS

\section{Introduction}

The significant role that atmospheric depositions may play on the biogeochemistry of the oceans has

\footnotetext{
*Corresponding author.

E-mail address: iilin@webmail.as.ntu.edu.tw ( I-I Lin).
}

been widely hypothesized but insufficiently documented (SCOR, 2004). Atmospherically derived material may affect marine biogeochemistry in a variety of ways. For example, the macro-nutrients, combined nitrogen and phosphorus, from atmospheric depositions may enhance primary production in the oceans directly (Paerl, 1997). Atmospherically 
derived iron may stimulate the uptake of nitrate in nutrient-rich water (de Baar et al., 1995; Timmermans et al., 2001) and foster nitrogen fixation in oligotrophic waters (Capone et al., 1997).

As a result of its unique combination of environmental conditions, the study site of the SouthEast Asian Time-series Study (SEATS) in the northern South China Sea has been hypothesized as a good location for further testing some of these hypotheses. Duce et al. (1991) reported that the concentration of nitrate in the aerosols over the South China Sea is moderately high. If this material is deposited into the South China Sea, it may stimulate primary production directly. The environmental conditions that are conducive to the occurrence of nitrogen fixation (Karl et al., 1997) can also be found readily in the northern South China Sea. First, the open South China Sea is oligotrophic. In most of the years, the concentrations of soluble reactive phosphate in the mixed layer at the SEATS station were less than $0.02 \mu \mathrm{M}$ while those of nitrate + nitrite were less than $0.1 \mu \mathrm{M}$ (Wu et al., 2003; Wong et al., 2007). Secondly, the water in the mixed layer is warm all year round, with temperature perpetually exceeding $20^{\circ} \mathrm{C}$. Thirdly, as a result of the high seasurface temperature, there is a strong thermocline and the upper water is strongly stratified year round (Wong et al., 2002). Fourthly, the atmospheric iron fluxes deposited to the northern South China Sea is among the highest fluxes in the global oceans (Duce and Tindale, 1991). Indeed, in their compilation of worldwide marine nitrogen fixation rates, Capone et al. (1997) found some of the higher nitrogen fixation rates in the South China Sea. Wong et al. $(2002,2007)$ also have suggested that the nutrient dynamics at the SEATS station is also consistent with the occurrence of nitrogen fixation.

An accurate and quantitative assessment of the aerosol input to the South China Sea is clearly a critical pre-requisite for delineating the interplay between atmospheric deposition and the biogeochemistry in the South China Sea. However, no such comprehensive data are available. Data from the Advanced Very High Resolution Radiometer (NOAA/AVHRR) have been used to evaluate aerosols in the South China Sea as part of global studies (Husar et al., 1997). However, AVHRR sensor was not originally designed with that purpose in mind. With limited spectral bands, it could only provide the estimate of total aerosol optical thickness (AOT). With the advancement in remote sensing, a dedicated sensor for aerosol study (the MODerate Resolution Imaging Spectro-radiometer-(MODIS)) is now available. As a result of its improved calibration and superior spectral resolution, this sensor can detect not only the improved-accuracy total AOT but also the size information of the aerosols (Kaufman et al., 2002; Remer et al., 2005). In addition to MODIS, data from the Quick Scatterometer, (QuikSCAT Liu et al., 1998) and the Measurements of Pollution in the Troposphere (MOPITT Pan et al., 1998) sensors are also useful to elucidate the sources of aerosols. In this paper, we examine the sources of aerosols to the South China Sea and the spatial and temporal variations of their influences in different parts of the region.

\section{Study area and data}

\subsection{Study area}

The South China Sea is one of the largest marginal seas of the world (Liu et al., 2002; Tseng et al., 2005). The main basin extends from the equator along the north-western coasts of Borneo to about $23^{\circ} \mathrm{N}$ along the southern shores of China and from about $105^{\circ} \mathrm{E}$ along the coasts of the Indo-Chinese Peninsula to $120^{\circ} \mathrm{E}$ along the eastern coasts of the Philippine Islands (Fig. 1). To its northern and southern boundaries, the region is bounded by the shelves along the southern coasts of China and the Sunda Shelf that further stretches to the Gulf of Thailand. The prevailing winds of the region are dominated by the northeast and southwest monsoon in the period of November-April and June-September, respectively. Thus, the primary remote aerosol sources can come from the north, west and south of the region. Four locations (Fig. 1) in the north to south transect across the South China Sea were chosen for more detailed analysis (Fig. 1). Station $1\left(115^{\circ} \mathrm{E}\right.$, $20^{\circ} \mathrm{N}$ ) was located at the vicinity of the Dongsha (Pratas) Islands. Station $2\left(116^{\circ} \mathrm{E}, 18^{\circ} \mathrm{N}\right)$ was situated at the same location as the SEATS station. Station 3 , at $116^{\circ} \mathrm{E}$ and $12^{\circ} \mathrm{N}$, was located in the vicinity of the Zhongsha Islands (Macclesfield Bank) at the deep central basin of the South China Sea where water depths exceeding $4000 \mathrm{~m}$ can be found. Station 4 , at $110^{\circ} \mathrm{E}$ and $5^{\circ} \mathrm{N}$, was located in the southern South China Sea around the edge of the Sunda Shelf. 


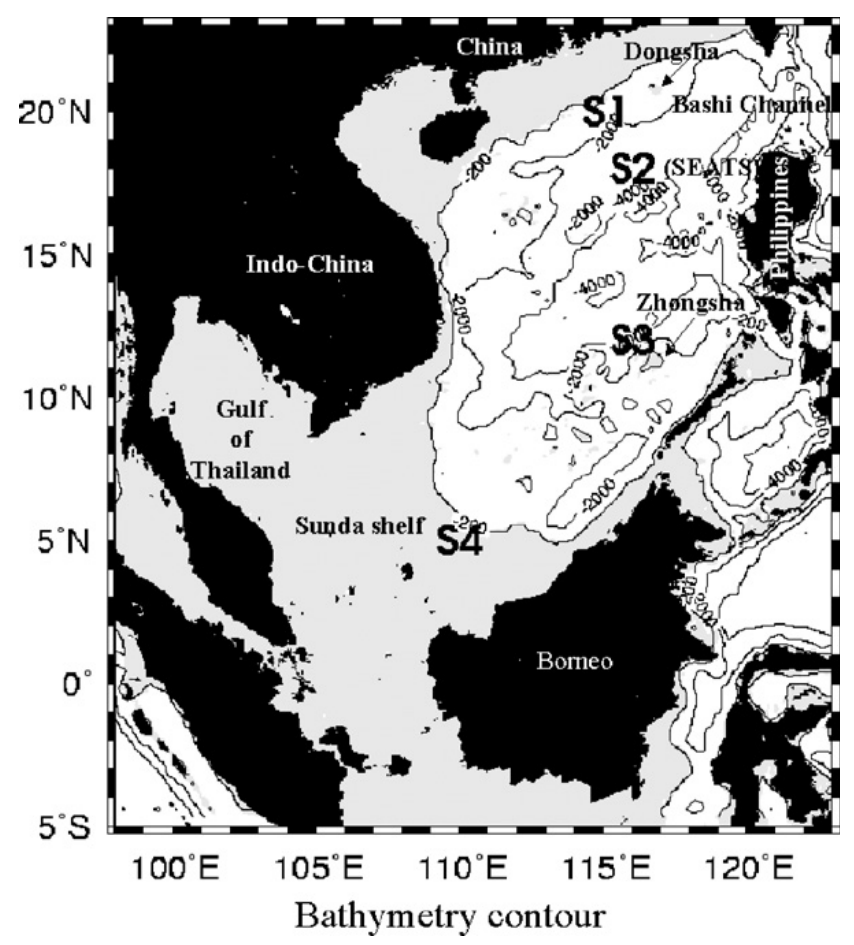

Fig. 1. Bathymetric map of the South China Sea showing the study domain and the four stations.

\subsection{Data}

Three-year (2002-2004) collection-4 Terra MODIS level-3 $\left(1^{\circ} \times 1^{\circ}\right)$ monthly mean AOT and fine-mode fraction (FMF) in the area between $5^{\circ} \mathrm{S}-45^{\circ} \mathrm{N}$ and $80-150^{\circ} \mathrm{E}$ were obtained from the NASA Giovanni MODIS Online Visualization and Analysis System (http://g0dup05u.ecs.nasa.gov/ Giovanni/). FMF is defined as the fraction of AOT that is attributed to the fine-mode particles (diameter $<1 \mu \mathrm{m}$ ) (Kaufman et al., 2002; Remer et al., 2005). Although MODIS data have been available since March 2000, FMF data prior to 2002 were not used in this study because those data had been contaminated by electronic crosstalk that reliable size information of the aerosols could not be obtained (Chu et al., 2005). MODIS true colour image and fire count (Giglio et al., 2003) data were also obtained (http://visibleearth.nasa. gov/ and http://earthobservatory.nasa.gov/) for analysis. In addition, the monthly mean ocean surface winds from the NASA QuikSCAT (Liu et al., 1998) at the spatial resolution of $0.25^{\circ} \times 0.25^{\circ}$ were used to illustrate the predominated long-range transport routes. Also used in interpreting biomass burning source is the carbon monoxide data from the NASA MOPITT measurements (Pan et al., 1998).

\section{Results and discussion}

\subsection{Continental aerosol sources}

As illustrated in Section 2, South China Sea is a marginal sea located near the Asian continent. Thus, in addition to the local maritime sea salt aerosol source, the contribution from continental sources also needs to be taken into account. These remote aerosol sources are identified with AOT values greater than $>0.6$ (colour code: orangered-white), which include urban/industrial pollution from Eastern China, dust from Taklimakan and Gobi Deserts, and biomass burning from Indo China, Sumatra, and Borneo.

\subsubsection{Eastern China}

Fig. 2 illustrated the 3-year monthly-averaged AOT overlaid by ocean surface winds of the South China Sea and surrounding areas. Elevated AOT $(>0.6)$ were observed in the eastern China from $103^{\circ}$ to $123^{\circ} \mathrm{E}$ and $20^{\circ}$ to $40^{\circ} \mathrm{N}$ throughout the year with peaks in the summer months (June-August). Using the AOT threshold of 0.6 as a guide, we could study the temporal variation of AOT values within the region. Areas with these high AOT values are shown as isolated spots in January (north of $28^{\circ} \mathrm{N}$ ), collocating with major densely populated/industrial cities in eastern China, such as Beijing $\left(116.28^{\circ} \mathrm{E}\right.$, $\left.39.54^{\circ} \mathrm{N}\right)$, Shanghai $\left(121.26^{\circ} \mathrm{E}, 31.12^{\circ} \mathrm{N}\right)$, Wuhan $\left(114.2^{\circ} \mathrm{E}, 30.37^{\circ} \mathrm{N}\right)$, Jinan $\left(117.02^{\circ} \mathrm{E}, 36.4^{\circ} \mathrm{N}\right)$, Chengdu $\left(104.02^{\circ} \mathrm{E}, 30.06^{\circ} \mathrm{N}\right)$, Chungqing $\left(106.33^{\circ} \mathrm{E}, 29.33^{\circ} \mathrm{N}\right)$, Nanning $\left(108.21^{\circ} \mathrm{E}, 22.47^{\circ} \mathrm{N}\right)$, Guangzhou $\left(113.3^{\circ} \mathrm{E}\right.$, $\left.23.1^{\circ} \mathrm{N}\right)$, and Hong Kong $\left(114.12^{\circ} \mathrm{E}, 22.51^{\circ} \mathrm{N}\right)($ denoted as stars in Fig. 2). The MODIS-derived FMF of this region (Fig. 3A) also show distinctly high values $(0.8-1)$, indicating the aerosols in this region are dominated by the fine mode. The concentrations of carbon monoxide (Fig. 3B) are generally greater than $150 \mathrm{ppbv}$ and higher concentrations $(>250 \mathrm{ppbv})$ are found in strong association with the previously listed populated/industrial cities (Fig. 3C). Kaufman et al. (2002) and Prospero et al. (2003) have suggested that anthropogenic aerosols produced in the burning of fossil fuel are predominated by fine-grain particles. Furthermore, the presence of elevated concentrations of carbon monoxide is indicative of incomplete combustion of fossil fuel. Thus, the locations of the centres of elevated AOT, the large FMF, and high concentration of carbon monoxide suggest that eastern China is a source region of anthropogenic aerosols 

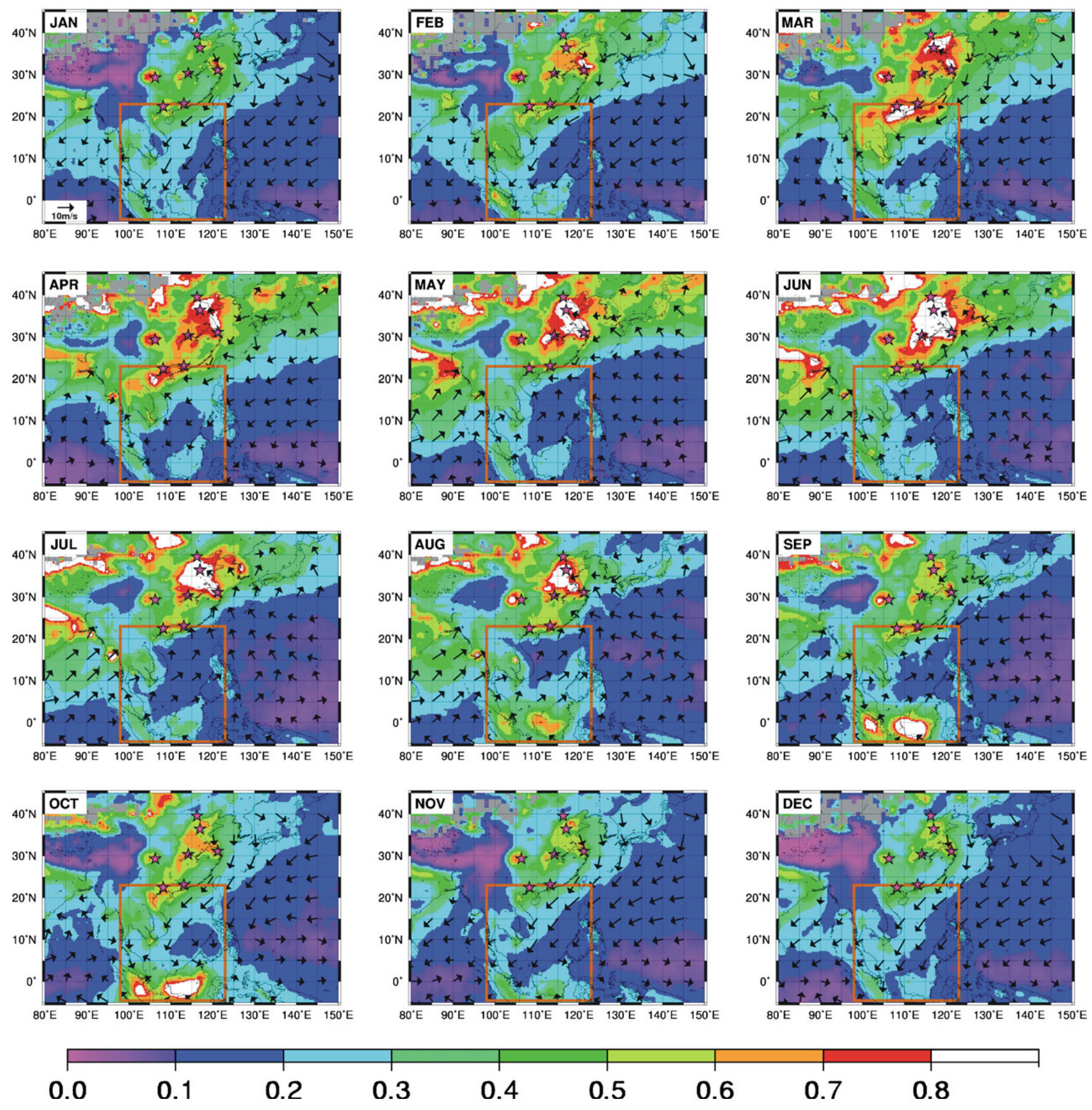

Fig. 2. Three-year (2002-2004) averaged total AOT from MODIS for each month in the South China Sea (boxed region) and neighbouring regions. QuikSCAT ocean-surface wind vectors are overlaid. Major Chinese cities are annotated in stars.

produced by the burning of fossil fuels (Kaufman et al., 2002; Prospero et al., 2003; Liu and Diamond, 2005; Richter et al., 2005).

QuikSCAT-derived wind vectors show strong northeasterly over the South China Sea from October to April (Fig. 2). Thus, during this period, the prevailing wind could carry the anthropogenic aerosols from eastern China to the region. In the months between June and September of directionally unfavourable southwest monsoon, aerosols from eastern China should have little or no influence on the aerosol in the South China Sea.

In the summer monsoon season outside China, the area in the vicinity of Calcutta, India (west of $92^{\circ} \mathrm{E}$ and between $17^{\circ}$ and $28^{\circ} \mathrm{N}$ ) is shown to be a potential aerosol source (Fig. 2). However, the contribution of this aerosol source should be small since the prevailing winds over India subcontinent 

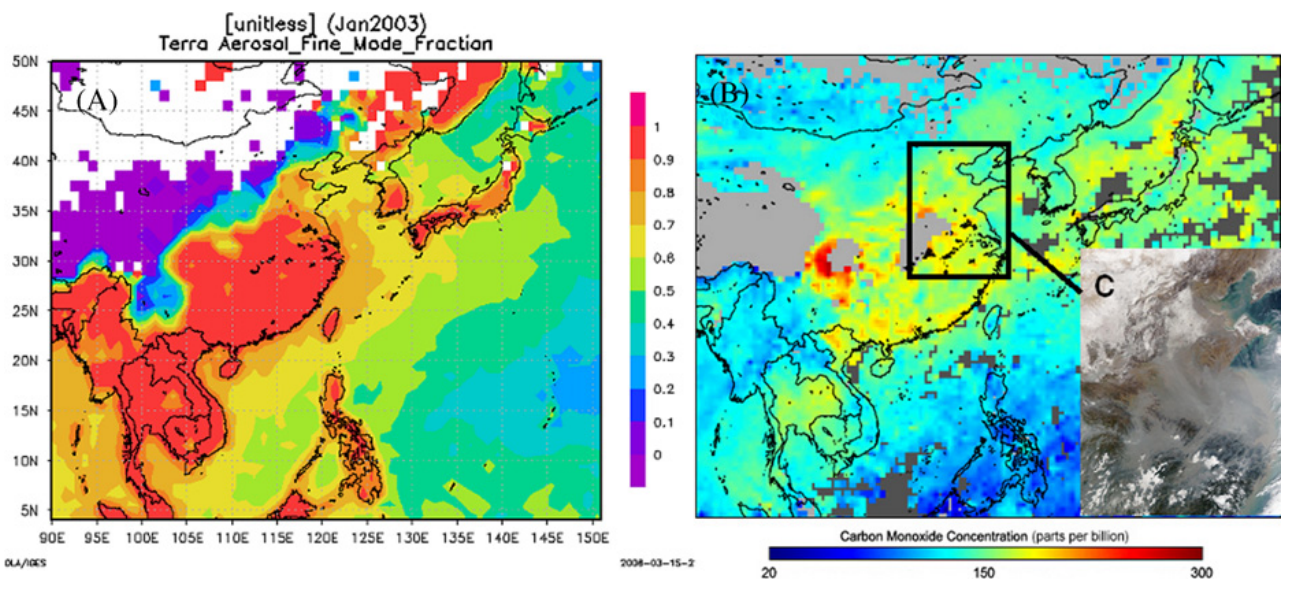

Fig. 3. (A) Monthly averaged MODIS Fine Mode Fraction Map of January 2003 in Asia; (B) image of MOPITT carbon monoxide concentration acquired in 1-20 January 2003 (source: http://earthobservatory.nasa.gov/); (C) shown at the lower-right corner of (B) MODIS true colour image of eastern China acquired on 13 January 2003 (source: http://visibleearth.nasa.gov/). (For interpretation of the references to colour in this figure legend, the reader is referred to the web version of this article.)

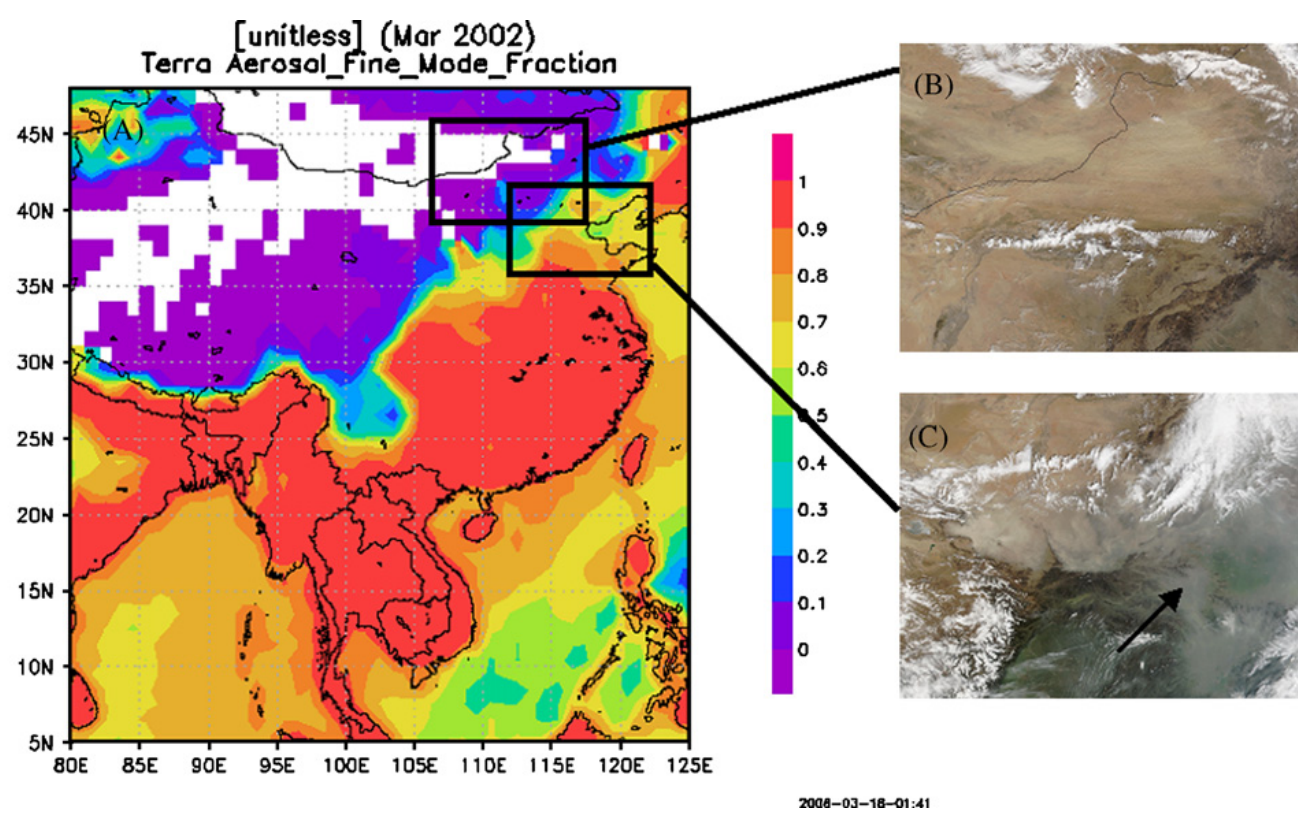

Fig. 4. (A) Monthly averaged MODIS Fine Mode Fraction Map of March 2002 covering Taklimakan Desert, Gobi Desert, and eastern China; (B) dust storm from the Gobi Desert on 15 March, 2002 (source: http://visibleearth.nasa.gov/); (C) MODIS true colour image on 29 March 2002 showing the mix of dust and fossil fuel burning aerosols. Dust (brown pixels) originated from the Gobi Desert is blown southeastwards and mixed with fossil fuel burning aerosols (gray pixels) in the eastern China during the south-eastward transporting passage of dusts (source: http://visibleearth.nasa.gov/). (For interpretation of the references to colour in this figure legend, the reader is referred to the web version of this article.)

would not be in favour of transporting aerosols to the South China Sea (Venkataraman et al., 2005).

\subsubsection{Gobi and Taklimakan deserts}

Two regions of high AOT ( $>0.6)$ were found between $89^{\circ}$ and $95^{\circ} \mathrm{E}$ and $35^{\circ}$ and $42^{\circ} \mathrm{N}$, and between $105^{\circ}$ and $117^{\circ} \mathrm{E}$ and $35^{\circ}-45^{\circ} \mathrm{N}$ in the northwestern China. The former was over the Taklimankan Desert and the latter was over the Gobi Desert. Both areas show high AOT values in March. With the increase in coverage and AOT, these two regions overlap by May. Areas of significantly high AOT ( $>0.8)$ were found between April and September but quickly dissipated and became minimal by November. The corresponding FMF in March 2002 (Fig. 4A) indicates that the aerosols over these two desert regions were predominated by coarse particles $(>1 \mu \mathrm{m})$ as the FMF values are typically $<0.1$ (colour coded: purple), as reported by Kaufman et al. (2002), Chu et al. (2005), and Remer et al. 
(2005). The MODIS true colour image over the Gobi Desert on 15 March 2002 (Fig. 4B) also indicates the yellowish colour that is typically characterized as dust. The dust-laden air mass is en route moving eastwards or southeastwards with the weather system (Sun et al., 2001). During the transport, dust aerosols are mixed with anthropogenic aerosols in eastern China (Bates et al., 2004; Lin et al., 2004; Wang et al., 2004; Chu et al., 2005; Meskhidze et al., 2005) before being further transported to the downwind ocean. Based upon in situ observations, Bates et al. (2004) reported that the aerosols in the Yellow Sea contained, in addition to Asian dust, high concentrations of sulfate, nitrate, organic, and elemental carbon, ingredients indicative of anthropogenic origins. The MODIS true colour image of 29 March 2002 (Fig. 4C) demonstrated the commingling of the aerosols from these two sources as the yellow dust blown from the Gobi Desert merged with the thick gray haze over eastern China. Thus, the most favourable time period of the year for the Central Asian dust to be transported to the South China Sea would be in March and April, coinciding with the northeast monsoon. However, these dusts would have been mixed with the anthropogenic aerosols from eastern China before they could reach the South China Sea.

\subsubsection{Indo China, Sumatra and Borneo}

The three other less extensive regions with AOT above 0.6 shown in Fig. 2 are in northern Laos and southwest China in the Indo-Chinese Peninsula $\left(99^{\circ}-103^{\circ} \mathrm{E}, 17^{\circ}-22^{\circ} \mathrm{N}\right)$ between March and April, in Sumatra $\left(100^{\circ}-105^{\circ} \mathrm{E}, 3^{\circ} \mathrm{S}-2^{\circ} \mathrm{N}\right)$ between August and October, and in southern Borneo $\left(107^{\circ}-117^{\circ} \mathrm{E}\right.$ and $4^{\circ} \mathrm{S}-2^{\circ} \mathrm{N}$ ) between August and October. The occurrence of high aerosol loading coincides with dry-season agricultural burning, as reported by Lelieveld et al. (2001). Shown in Fig. 5 are MODIS images of smoke over the Indo-Chinese Peninsular and southern Borneo in March and October 2004, respectively. Similar to aerosols from fossil fuel burning, the size distribution of the smoke generated by biomass burning appears also to be dominated by fine-mode particles (Kaufman et al., 2002; Remer et al., 2005) with FMF values greater than 0.9. An example of FMF derived over the Indo-Chinese Peninsula in March 2002 is shown in Fig. 4A.

Because of long distance, the prevailing northeast monsoon in March and April would be difficult in transporting aerosols from the Indo-Chinese Peninsula to the South China Sea, whereas the southwest monsoon in August and September would be relatively easy to carry smoke particles produced in Sumatra and southern Borneo to the region. By October, as the prevailing wind switches abruptly from the southwest to the northeast, it becomes unfavourable for the transport to the South China Sea, although biomass burning smoke was still present over Sumatra and southern Borneo.

\subsection{Monthly distribution of aerosols over the South China Sea}

\subsubsection{Total AOT}

The monthly distributions of total AOT averaged from 2002 to 2004 in the South China Sea are shown in the boxed region in Fig. 2. In comparison to the open western Pacific Ocean far away from the continents, terrestrial influence is clearly seen.
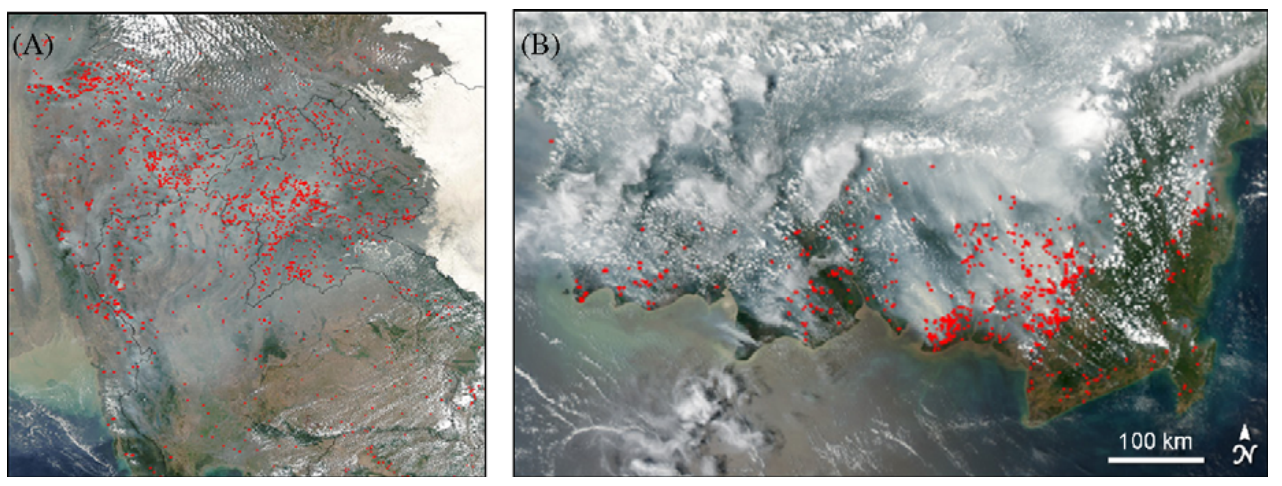

Fig. 5. MODIS fire spot (red spots) maps of (A) Indo China (covering clockwise from top left Myanmar, China, Vietnam, Laos, Cambodia, and Thailand) on 24 March 2004 and (B) southern Borneo on 13 October 2004 (source: http://earthobservatory.nasa.gov/). (For interpretation of the references to colour in this figure legend, the reader is referred to the web version of this article.) 
For example, at east of the Philippines between $125-150^{\circ} \mathrm{E}$ and $0-20^{\circ} \mathrm{N}$ where the maritime sea salt aerosol dominates, the AOT values are typically $\leqq 0.1$. However in the South China Sea, such low AOTs of $\leqq 0.1$ are rarely observed (boxed region in Fig. 2). One can see that the terrestrial sources of aerosols have significant influences on AOT nearly over the entire South China Sea. Using AOT $\sim 0.2$ as a threshold (Fig. 2), we can see the seasonal intrusion from various land aerosol sources to the South China Sea. During the northeast monsoon period form October to April, AOT values greater than 0.2 are observed in the northwestern part of the sea (north of $10^{\circ} \mathrm{N}$ and west of $115^{\circ} \mathrm{E}$ ), which suggests that aerosols of terrestrial origin are carried to the region by the prevailing northeasterly. The spatial coverage of the elevated AOT is shown to be more extensive in March than the rest of the season, especially during dust outbreaks.

After April, the areas of AOT $>0.2$ isopleths retreate progressively towards the north as the northeast monsoon dissipates and eventually switches to the southwest monsoon. The retreat reaches a maximum in July and August at the peak of the southwest monsoon season. In the southwestern part of the South China Sea (south of $10^{\circ} \mathrm{N}$ and west of $115^{\circ} \mathrm{E}$ ), the AOT exceeding 0.2 is shown to cover nearly the entire region in August during the biomass-burning season in Sumatra and Borneo. The transport of smoke aerosols from biomass burning at the peak of southwest monsoon extends to the southeastern and northeastern South China Sea and reaches as far as the Luzon Island. In September and October, though the emission of the aerosols from these sources is higher, the unfavourable northeast wind suppresses the northward transport. As a result, the area of AOT $>0.2$ retreats southeastward to about $5^{\circ} \mathrm{N}$. Such retreat reaches a maximum in November as the biomass burning diminishes. After November, the area of AOT $>0.2$ advances southeastward into the southwestern South China Sea as the northeast monsoon strengthens and brings aerosols into this region from the north. In the absence of biomass burning aerosols and between the transition from northeast monsoon to southwest monsoon (i.e., from May to July), the aerosol loading reaches a minimum $(\mathrm{AOT}<0.2)$ in the South China Sea.

\subsubsection{FMF, AOT-cs, and AOT-cd}

The transported aerosols can be further examined by the particle sizes derived from the MODIS retrievals. The FMF during the dust outbreaks in March at the source region of the Asian dust over the Gobi Desert and the Taklimakan Desert is typically below 0.1 . In the eastern China and over the Indo-Chinese Peninsula in the same time period when the fossil fuel burning and biomass burning are most intensive the AOT values are typically above 0.8 (Fig. 4A). The monthly averaged FMF values in the study area shown in Fig. 6 have values greater than 0.9 over land surrounding the South China Sea. This indicates that fine aerosols are the primary aerosols transported to the South China Sea from the remote continental sources. Approaching the deeper central basin of the sea, FMF values decreases, indicating an increasing contribution from the locally produced sea salt particles.

In most of the time, these fine aerosols likely originate from eastern China as a result of fossil fuel burning. However, during the outbreak of the Asian dust between February and May (Sun et al., 2001; Chu et al., 2005), though these dust are predominantly coarse particles in nature, the contribution from secondary fine-mode particles cannot be completely ruled out, especially in the region far away the sources, such as in the South China Sea. Concomitantly, in the southern South China Sea south of about $7^{\circ} \mathrm{N}$, fine-grained material is carried into the Sea from July to October during the southwest monsoon and the early stage in the development of the northeast monsoon. It then retreats for the rest of the year as the northeast monsoon sets in.

The contribution of the coarse aerosols, i.e., AOT-c, can be estimated as (Chu et al., 2005; Kaufman et al., 2005):

$\mathrm{AOT}-\mathrm{c}=\operatorname{AOT}(1-\mathrm{FMF})$.

AOT-c generally includes the contribution from dust (i.e., AOT-cd) and sea salt (i.e., AOT-cs). However, in a remote dust-free location, AOT-cs can be the only contributor to AOT-c; thus, AOT-c = AOT-cs. Also, one can take advantage of the fact that AOT-cs can be linearly estimated by ocean-surface wind speed (Smirnov et al., 2003; Kaufman et al., 2005). Based upon the co-located monthly averaged QuikSCAT wind speed $(\mathrm{m} / \mathrm{s})$ in the centre of the South China Sea (at $115^{\circ} \mathrm{E}, 15^{\circ} \mathrm{N}$ ), i.e., a location where land influence is minimal, we can obtain a linear least, square relationship as shown in Fig. 7 that

$$
\begin{gathered}
\text { AOT-cs }=0.0128 \mathrm{WS}-0.0278, \\
\quad N=30 ; \quad r=0.72
\end{gathered}
$$



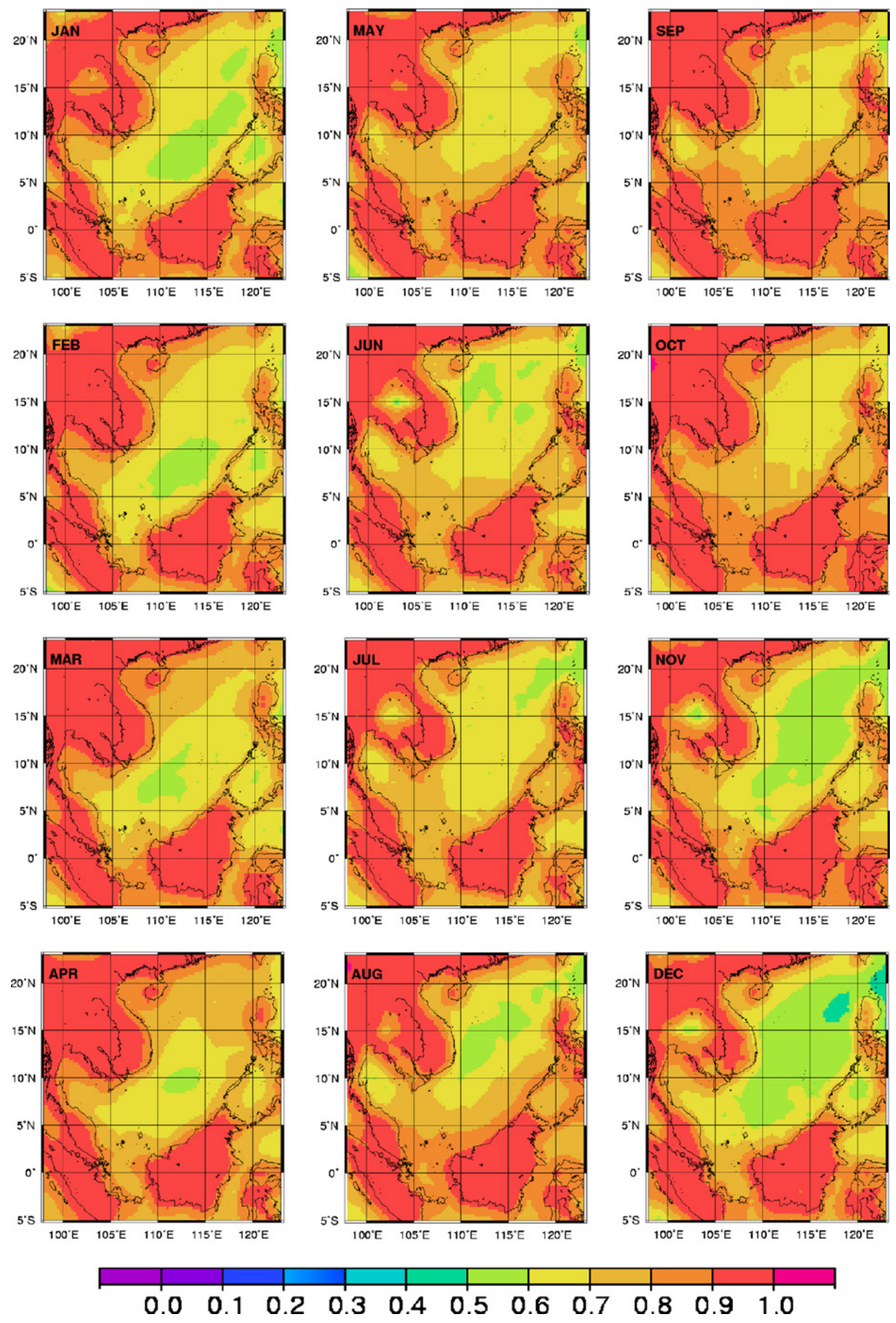

Fig. 6. Three-year (2002-2004) averaged Fine-Mode Fraction from MODIS for each month in the South China Sea.

and

AOT-cd $=$ AOT $-\mathrm{c}-$ AOT-cs.

According to this estimation, it is found in the South China Sea that AOT-cd is nearly undetectable $(<0.05)$ in most of the months except in March-April (Fig. 8) as the transport of Asian dusts reaches its maximum. On the other hand, the AOT-cs values are found in the range of 0.050.08 in many parts of the South China Sea, and in most of the months except in December that AOT-cs reaches the maximums of $0.08-0.10$ (in the central basin) at the peak of the northeast monsoon (Fig. 9). 
20002004/6r11month month-averaged Scotter Diagram longitude=115 latitude=15

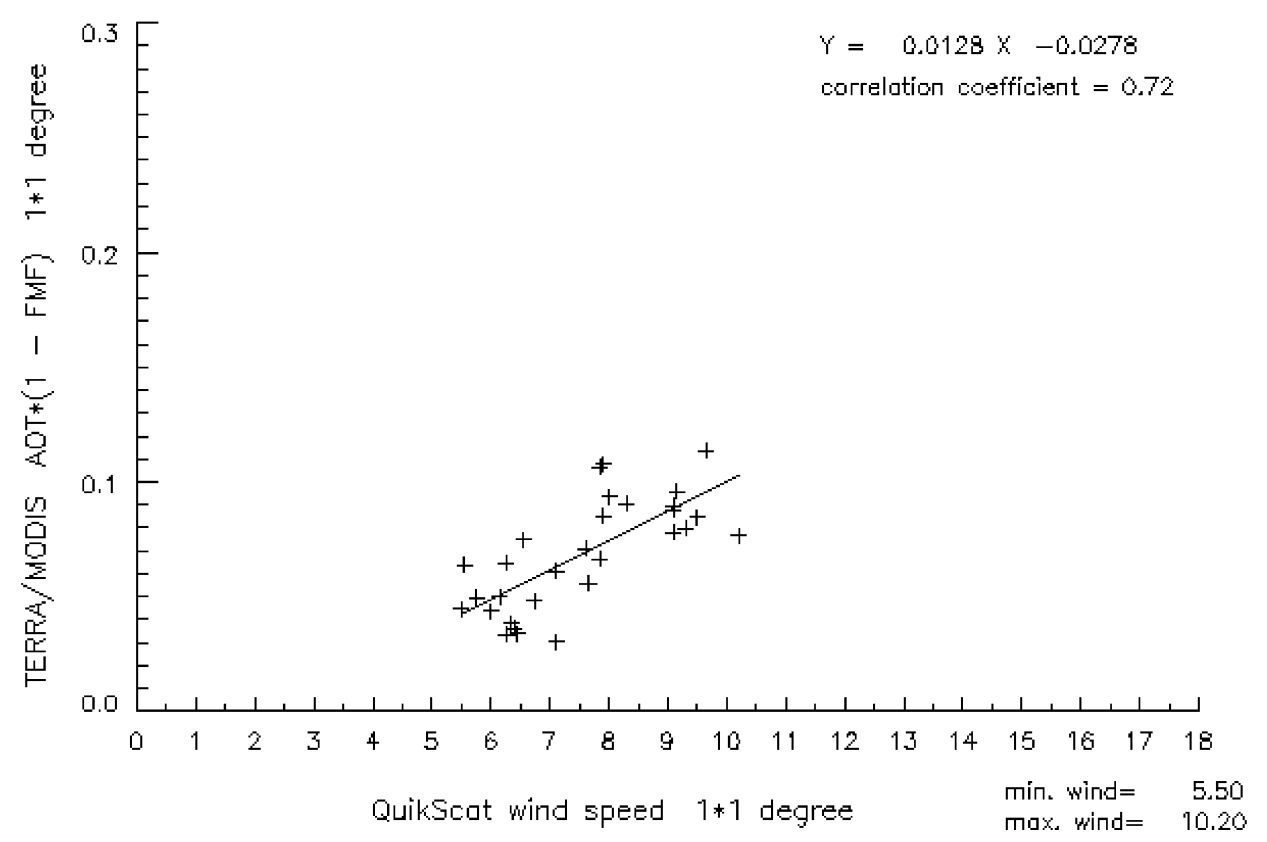

Fig. 7. Scatter plot of MODIS AOT-c (i.e., coarse AOT) and QuikSCAT ocean surface wind speed during June-November in 2000-2004 at $115^{\circ} \mathrm{E}, 15^{\circ} \mathrm{N}$ with least-squares fitted regression line.

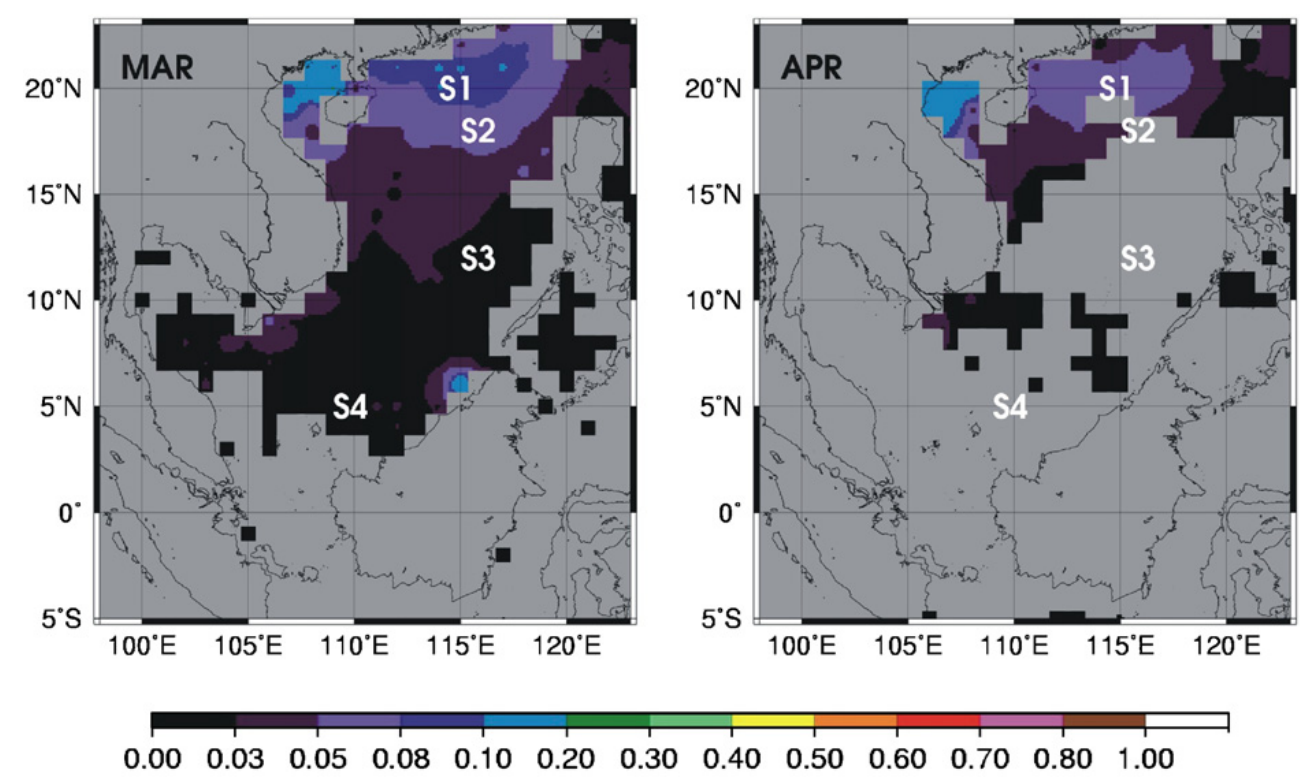

Fig. 8. Three-year (2002-2004) averaged AOT-cd (i.e., coarse dust AOT) for March and April in the South China Sea.

\subsection{Temporal variations in AOT at the four study stations}

The variations of the monthly mean AOT-f, AOT-cd, AOT-cs, and wind speed at Stations 1-4 (Fig. 10) from 2002 to 2004 are shown in Fig. 10, where AOT- $=$ AOT $\times$ FMF. The values of AOTcd and AOT-cs below 0.05 are not shown since those values are on the same order of magnitude as the uncertainty of the measurements (Chu et al., 2005; Remer et al., 2005).

Station $1(\mathrm{~S} 1)$, located at $115^{\circ} \mathrm{E}, 20^{\circ} \mathrm{N}$, is closest to the aerosol sources from eastern China. In other words, fine aerosols clearly dominate all times. The variation of AOT-f is the largest among the four stations, in the range between 0.1 and 0.8 . The AOT-f reached its minimum $(\sim 0.1)$ during the summer southwest monsoon from June to August. 

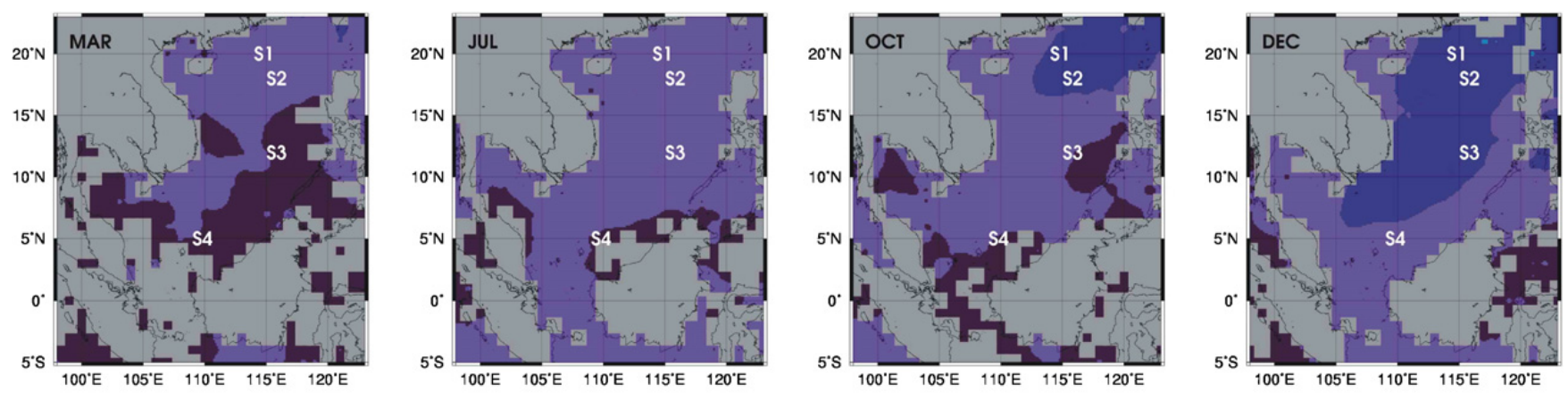

$\begin{array}{lllllllllllll}0.00 & 0.03 & 0.05 & 0.08 & 0.10 & 0.20 & 0.30 & 0.40 & 0.50 & 0.60 & 0.70 & 0.80 & 1.00\end{array}$

Fig. 9. Three-year (2002-2004) averaged AOT-cs (i.e., coarse salt AOT) for representative month of each season in the South China Sea.
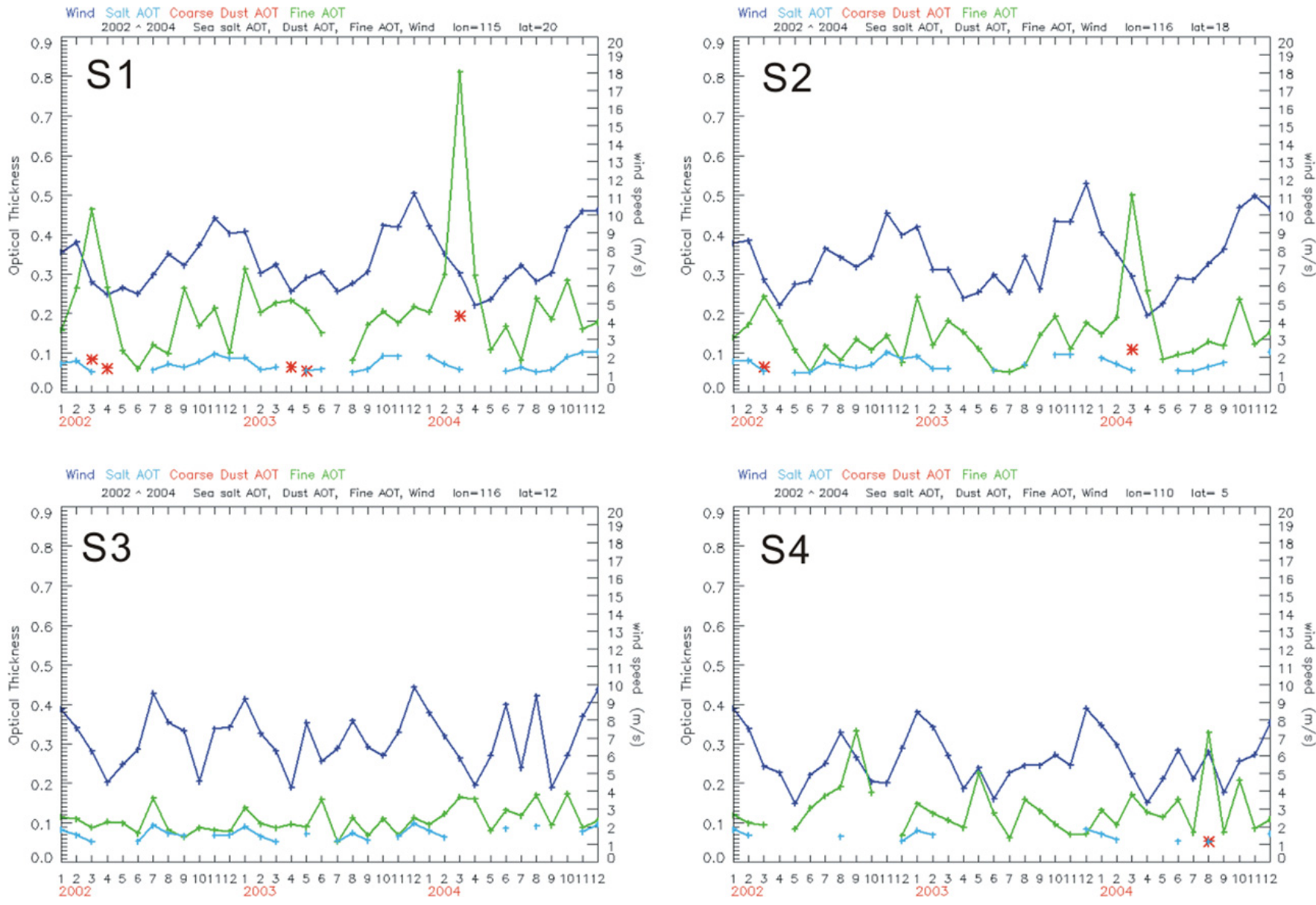

Fig. 10. Time series (at monthly interval) of AOT-f (in green), AOT-cd (in red), and AOT-cs (in light blue), and QuikSCAT wind speed (in dark blue) of the four representative stations. (For interpretation of the references to colour in this figure legend, the reader is referred to the web version of this article.)

The wind speed during this period was also minimal. These suggest that, as a result of the weaker wind and the long distance from the source regions, the influence of the aerosols produced by biomass burning in Sumatra and Borneo is minimal in the northern South China Sea. On the other hand, from September to January when the northeasterly prevailed, AOT-f increased rapidly to $0.2-$ 0.3 , indicating the strong influence of continental sources of aerosols (industrial/urban and biomass burning) at S1. In the year of 2002 and 2004, AOT-f increased sharply from January to March, to reach 
their respective maximum values of 0.4 and 0.8 , before starting to decrease to the minimum in the summer. In 2003, while a pronounced maximum was not observed in March, AOT-f remained elevated at around 0.25 into May before it started to decrease towards the minimum values in the summer. These patterns suggest that source strength could play a role in the transport of aerosols to the northern South China Sea as the occurrence of the maximum coincided with the Asian dust outbreak events. Thus, while the fine aerosols over the northern South China Sea are primarily of anthropogenic origin prior to February, the contribution to the fine-mode fraction from the Asian dust also seems possible. During March and April, AOT-cd is derived at more pronounced levels of 0.1 and above, which suggests that Asian dusts could reach the northern South China Sea. Note that the AOT-cd values used in analysis are derived from the MODIS monthly aerosol products. The levels of aerosol loading could be much higher for individual events.

Inter-annual variation of AOT-f and AOT-cd is shown to be significant, especially during the dust season. We definitely need to take it into account in studying the input of dust to the region. Throughout the year, AOT-cs are found between 0.05 and 0.15 ; below 0.1 in most of the months and above 0.1 in November and January during the height of the northeast monsoon when the wind speed is highest. The inter-annual variation of AOT-cs is significantly lower compared to dust.

Station 2 was situated at the same location as the SEATS station, farther offshore than Station 1 but still in the northern South China Sea. As expected, the temporal patterns in the monthly mean AOT-f, AOT-cd, AOT-cs and wind speed at Station 2 were similar to those at Station 1. In terms of the absolute values, AOT-cs and wind speed remained approximately the same while the values AOT-f, between 0.1 and 0.5 , and AOT-cd, between undetectable and 0.1 , were significantly reduced. These trends affirm the diminishing influence of the fine aerosols from the north over China, with increasing distance from the major continental emission sources.

Station 3 was located in the central basin of the South China Sea, the farthest from any landmass. As a result, the AOT-f was shown to be the lowest in the range of $0.1-0.2$. However, the wind speed indicates higher wind speed during the southwest monsoon at Station 3, as compared to Station 1. With higher wind speed of the southwest monsoon within a closer proximity to Borneo and Sumatra, the influence of the aerosols from biomass burning in these areas in the summer months became evident. Thus, in addition to the increase in AOT-f in winter as a result of aerosol transport from eastern China, an increase of similar magnitude also could be observed in the summer but from a different source. In terms of the fraction of coarse particles, AOT-cd was undetectable at Station 3, whereas AOT-cs stayed at the level of 0.05-0.01, similar to other stations.

At Station 4 in the southern South China Sea, while the variations in wind speed still indicated an increase of similar magnitude during the northeast monsoon in the winter and the southwest monsoon in the summer as at Station 3, an increase in AOT-f in the winter was not prominent. This suggests that the influence of the aerosols from China is minimal in the southern South China Sea. A maximum in AOT-f, reaching 0.3 , was found in the summer. This indicates that the dominating influence on the fine aerosols in this region is the aerosols produced in biomass burning in Borneo and Sumatra during the summer months. In the coarse-grained fraction, AOT-cd was undetectable as at Station 3 while AOT-cs stayed at a rather constant level of $0.05-0.1$ throughout the year as in all the other stations.

\section{Conclusions}

Fine aerosol particles dominant in the South China Sea result from multiple remote sources. Anthropogenic particles produced by fossil burning in the eastern China are dominant during the northeast monsoon season between October and April. The fine-grained fraction of the dusts produced in the deserts in Central Asia could also contribute in the latter part of the monsoonal season, i.e. in March and April. The combined strength of these two sources is strong enough in March and April so that the maximum AOT was found in these 2 months rather than when the maximum speed of the northeast prevailing wind is reached in November-January. Nonetheless, a conspicuous maximum AOT could only be observed in the early spring in the northern South China Sea where the SEATS station is located. This suggests that the influence of aerosols from China was primarily confined to the northern South China Sea and few of these aerosols reach the southern South China Sea. In contrast, the dominant fine particles in the southern South China Sea are 
produced by biomass burning in Sumatra and Borneo from August to October and carried by the southwest monsoon. Since the chemical composition and physical properties of fine particles transported to the South China Sea could vary from time to time, their relative contributions through the transport to the South China Sea are temporally and spatially dependent. Thus, the impact of aerosols on the biogeochemistry of this region is also temporally and spatially varying. This impact cannot be accessed accurately until aerosol properties from each source are fully understood. This suggests that previous assumptions of dust being the sole material deposited to the South China Sea through transport (Wu et al., 2001, 2003; Wong et al., 2002) must be re-evaluated by taking into account these multiple aerosol sources as well as their spatial and temporal variability.

\section{Acknowledgements}

Many thanks to the reviewers for their careful review and constructive suggestions. Special thanks to Dr. Allen Chu from the NASA Goddard Space Flight Center for his really helpful comments, which greatly improved this paper. This work is supported by the National Science Council, Taiwan (NSC 952119-M-002-040-AP1, NSC 96-2111-M-002-001, and NSC 95-2611-M-002-024-MY3).

\section{References}

Bates, T.S., Quinn, P.K., Coffman, D.J., Covert, D.S., Miller, T.L., Johnson, J.E., Carmichael, G.R., Uno, I., Guazzotti, S.A., Sodeman, D.A., Prather, K.A., Rivera, M., Russell, L.M., Merrill, J.T., 2004. Marine boundary layer dust and pollutant transport associated with the passage of a frontal system over eastern Asia. Journal of Geophysical Research 109.

Capone, D.G., Zehr, J.P., Paerl, H.W., Bergman, B., Carpenter, E.J., 1997. Trichodesmium, a globally significant marine cyanobacterium. Science 276, 1221-1229.

Chu, D.A., Remer, L.A., Kaufman, Y.J., Schmid, B., Redemann, J., Knobelspiesse, K., Chern, J.-D., Livingston, J., Russell, P.B., Xiong, X., Ridgway, W., 2005. Evaluation of aerosol properties over ocean from moderate resolution imaging spectroradiometer (MODIS) during ACE-Asia. Journal of Geophysical Research 110, D07308.

de Baar, H.J.W., de Jong, J.T.M., Bakker, D.C.E., Löscher, B.M., Veth, C., Bathmann, U., Smetacek, V., 1995. Importance of iron for phytoplankton spring blooms and $\mathrm{CO}_{2}$ drawdown in the southern ocean. Nature 373, 412-415.

Duce, R.A., Tindale, N.W., 1991. Atmospheric transport of iron and its deposition in the ocean. Limnology and Oceanography $36(8), 1715-1726$.
Duce, R.A., Liss, P.S., Merrill, J.T., Atlas, E.L., Buat-Menard, P., Hicks, B.B., Miller, J.M., Prospero, J.M., Arimoto, R., Church, T.M., Ellis, W., Galloway, J.N., Hansen, L., Jickells, T.D., Knap, A.H., Rheinhardt, K.H., Schneider, B., Sudine, A., Tokos, J.J., Tsunogai, S., Wollast, R., Zhou, M., 1991. The atmospheric input of trace species to the world ocean. Global Biogeochemical Cycles 5, 193-259.

Giglio, L., Descloitres, J., Justice, C.O., Kaufman, Y., 2003. An enhanced contextual fire detection algorithm for MODIS. Remote Sensing of Environment 87, 273-282.

Husar, R.B., Prospero, J.M., Stowe, L.L., 1997. Characterization of tropospheric aerosols over the oceans with the NOAA advanced very high resolution radiometer optical thickness operational product. Journal of Geophysical Research 102 (D14), 16889-16909.

Karl, D.M., Letelier, R., Tupas, I., Dore, J., Christian, J., Hebel, D., 1997. The role of nitrogen fixation in biogeochemical cycling in the subtropical North Pacific Ocean. Nature 388, 533-538.

Kaufman, Y.J., Tanré, D., Boucher, O., 2002. A satellite view of aerosols in the climate system. Nature 419, 215-223.

Kaufman, Y.J., Koren, I., Remer, L.A., Tanré, D., Ginoux, P., Fan, S., 2005. Dust transport and deposition observed from the terra-moderate resolution imaging spectroradiometer (MODIS) spacecraft over the Atlantic ocean. Journal of Geophysical Research 110, D10S12.

Lelieveld, J., Crutzen, P.J., Ramanathan, V., Andreae, M.O., Brenninkmeijer, C.A.M., Campos, T., Cass, G.R., Dickerson, R.R., Fischer, H., de Gouw, J.A., Hansel, A., Jefferson, A., Kley, D., de Laat, A.T.J., Lal, S., Lawrence, M.G., Lobert, J.M., Mayol-Bracero, O.L., Mitra, A.P., Novakov, T., Oltmans, S.J., Prather, K.A., Reiner, T., Rodhe, H., Scheeren, H.A., Sikka, D., Williams, J., 2001. The Indian ocean experiment: widespread air pollution from south and southeast Asia. Science 291, 1031-1036.

Lin, C.-Y., et al., 2004. Long-range transport of Asian dust and air pollutants to Taiwan. Terrestrial, Atmospheric and Oceanic Sciences 15, 759-784.

Liu, J., Diamond, J., 2005. China's environment in a globalizing world. Nature 435, 1179-1186.

Liu, K.K., Chao, S.Y., Shaw, P.T., Gong, G.C., Chen, C.C., Tang, T.Y., 2002. Monsoon-forced chlorophyll distribution and primary production in the South China Sea: observations and a numerical study. Deep-Sea Research I 49 (8), $1387-1412$.

Liu, W.T., Tang, W., Polito, P.S., 1998. NASA scatterometer provides global ocean-surface wind fields with more structures than numerical weather prediction. Geophysical Research Letters 25, 761-764.

Meskhidze, N., Chameides, W.L., Nenes, A., 2005. Dust and pollution: a recipe for enhanced ocean fertilization? Journal of Geophysical Research 110, D03301.

Paerl, H.W., 1997. Coastal eutrophication and harmful algal blooms. Importance of atmospheric deposition and groundwater as "new": nitrogen and other nutrient sources. Limnology and Oceanography 42, 1154-1165.

Pan, L., Gille, J.C., Edwards, D.P., Bailey, P.L., Rodgers, C.D., 1998. Retrieval of tropospheric carbon monoxide for the MOPITT experiment. Journal of Geophysical Research 103, 32,277-32,290.

Prospero, J.M., Savoie, D.L., Arimoto, R., 2003. Long-term record of nss-sulfate and nitrate in aerosols on Midway 
Island, 1981-2000: evidence of increased (now decreasing?) anthropogenic emissions from Asia. Journal of Geophysical Research 108 (D1), 4019.

Remer, L.A., Kaufman, Y.J., Tanré, D., Mattoo, S., Chu, D.A., Martins, J.V., Li, R-R., Choku, C., Levy, R.C., Kleidman, R.G., Eck, T.F., Vermote, E., Holben, B.N., 2005. The MODIS aerosol algorithm, products and validation. Journal of the Atmospheric Sciences 62, 947-973.

Richter, A., Burrows, J.P., Nub, H., Granier, C., Niemeier, U., 2005. Increase in tropospheric nitrogen dioxide over China observed from space. Nature 437, 129-132.

SCOR, 2004. The surface ocean-lower atmosphere study. Science plan and implementation strategy. IGBP Report 50. IGBP, Sweden, 88pp.

Smirnov, A., Holben, B.N., Eck, T.F., et al., 2003. Effect of wind speed on columnar aerosol optical properties at Midway Island. Journal of Geophysical Research 108, D24 Art. No. 4802.

Sun, J., Zhang, M., Liu, T., 2001. Spatial and temporal characteristics of dust storms in China and its surrounding regions, 1960-1999: relations to source area and climate. Journal of Geophysical Research 106 (D10), 10,325-10,333.

Timmermans, K.R., Gerringa, L.J., de Baar, H.J.W., Wagt, H.J.W., van der Wagt, B., Veldhuis, M.J.W., Boye, M., Jeroen, T.M., de Jong, Croot, P.L., 2001. Growth rates of large and small Southern Ocean diatoms in relation to availability of iron in natural seawater. Limnology and Oceanography 46 (2), 260-266.
Tseng, C.M., Wong, G.T.F., Lin, I.I., Wu, C.R., Liu, K.K., 2005. A unique seasonal pattern in phytoplankton biomass in lowlatitude waters in the South China Sea. Geophysical Research Letters $32,8$.

Venkataraman, C., Habib, G., Eiguren-Fernandez, A., Miguel, A.H., Friedlander, S.K., 2005. Residential biofuels in South Asia: carbonaceous aerosol emissions and climate impacts. Science 307, 1454-1456.

Wang, C.-C., Lee, C.-T., Liu, S.C., Chen, J.-P., Liu, S.C., 2004. Aerosol characterization at Taiwan's tip during ACEAsia. Terrestrial, Atmospheric and Oceanic Sciences 15, 839-855.

Wong, G.T.F., Chung, S.-W., Shiah, F.-K., Chen, C.-C., Wen, L.-S., Liu, K.-K., 2002. Nitrate anomaly in the upper nutricline in the northern South China Sea-evidence for nitrogen fixation. Geophysical Research Letters 29 (23), 2097.

Wong, G.T.F., Tseng, C.-M., Wen, L.-S., Chung, S.-W., 2007. Nutrient dynamics and nitrate anomaly at the SEATS station. Deep-Sea Research II, this issue [doi:10.1016/j.dsr2.2007. 05.011].

Wu, J., Boyle, E., Sunda, W., Wen, L.-S., 2001. Soluble and colloidal iron in the oligotrophic north Atlantic and north Pacific. Science 293, 847-849.

Wu, J., Chung, S.-W., Wen, L.-S., Liu, K.-K., Chen Lee, Y.-L., Chen, H.-Y., Karl, D.M., 2003. Dissolved inorganic phosphorus, dissolved iron, and Trichodesmium in the oligotrophic South China Sea. Global Biogeochemical Cycles 17 (1), 1008. 